\title{
A Komplex Instrukciós Program mint iskolai innováció
}

\author{
K. Nagy Emese \\ Miskolci Egyetem Tanárképző Intézet főigazgatója \\ emese.nagy@uni-miskolc.hu
}

\begin{abstract}
A Stanford Egyetemen kidolgozott Complex Instruction oktatási módszer magyar innovációja a hejökeresztúri iskolában kidolgozott Komplex Instrukciós Program. Írásunk célja annak feltárása, hogy ez a hazai, a tudásban heterogén tanulói csoportok kezelésére alkalmas metódus miért és hogyan lett országosan ismert és elfogadott módszer. Választ keresünk arra, hogy miért dönthetett közel kétszáz iskola a program bevezetése mellett függetlenül attól, hogy hátrányos helyzetú vagy éppen elit tanulói összetétellel rendelke$z i k$.
\end{abstract}

Kulcsszavak: innováció, komplex, instrukciós, program, KIP

DOI: 10.37205/TEL-hun.2020.3-4.07

\section{Bevezetés}

Írásunk első, rövidebb részében meghatározzuk az innováció fogalmát, és hozzákapcsoljuk azt az iskolához mint tanulószervezethez, mivel ez utóbbi elengedhetetlen része a sikeres innovációnak, míg a második, terjedelmesebb részben a hazai innovációs folyamat eredményeként létrejött Komplex Instrukciós Program létrejöttének és sikerének bemutatása történik, amely motiválóan hatott Magyarország sok iskolájára.

\section{Az innováció és az iskola mint tanulószervezet kapcsolata}

Az innováció változás, amely az addig megszokott rendszerbe a szokatlan, az ismeretlen erejével tör be, és olyan folyamatokat indít el, amelyek miatt a rendszer megújul (Oslo kézikönyv, 2005), és amely fogalom a gazdaság szférájában történő alkalmazás után a pedagógia szakterületén megvalósuló újítások létrehozását, elterjesztését is jelöli.

A meghatározásból következően a sikeres oktatási intézmények jellemzője a megújulásra való törekvés, amely magában foglalja a változásokra és az innovációra való gyors reagálást, a minőségtudatosságot és - lehetőség szerint - az egész 
tantestület bevonását, amely a hozzáadott érték, a tudástőke egyik teremtője. Halász (2007), majd Halász, Fazekas és Lukács (2020) szerint azonban az értékes innovációs folyamatok csak olyan oktatási szervezetekben lehetségesek, amelyekben intenzív és folyamatos belső tanulás zajlik. Úgy vélik, hogy a szervezeti tanulás komplex folyamat, amelynek célja a szervezet fejlődése, és amelyben az egyéni és a csoportos tanulás fontos szerepet kap, valamint az egyén tanulása és a szervezet fejlődése kölcsönösen egymás feltételei, segítői. A szervezeti tanulás tehát a tanulószervezetek jellemzője, amelynek során a tantestület tagjai képesek tapasztalataik alapján új tudást létrehozni, és azt a szervezeten belül elterjeszteni annak érdekében, hogy az elérhető és felhasználható legyen a többi pedagógus számára is. Az ilyen szervezetben a pedagógusok képesek elemezni megfigyeléseiket, következtetéseket levonni sikereikből és kudarcaikból. Egy tanulószervezetként működő iskolában a pedagógusok értik az intézmény céljait, és azonosulnak azokkal, elégedettek a munkájukkal, azonban ha problémahelyzetbe kerülnek, tudják, hogy a szervezetben milyen mechanizmusok állnak rendelkezésre annak megváltoztatására.

\section{A Komplex Instrukciós Program mint sikeres hazai iskolai innováció}

\section{A hazai Komplex Instrukciós Program megszületése}

A Komplex Instrukciós Program (továbbiakban KIP) tekintetében az innováció fogalmát úgy fordítjuk le, hogy az egy olyan javító szándékú pedagógiai tevékenység, új ismeretanyagokba történő befektetés, amely új vagy továbbfejlesztett módszer, eljárások és szolgáltatás megvalósításához vezet. A fogalom meghatározásából a javitó szándékú változtatást és továbbfejlesztett módszer meghatározást szeretnénk erősebben a KIP-hez kapcsolni, hiszen az, bár alapgondolatában nem új, de javítást szolgáló bevezetése az eredetihez képest jelentősen javított, újabb elemekkel kiegészített módszer, innováció lett. A KIP hazai innovációjához kapcsolódik, hogy a Stanford Egyetemről származó metódushoz nem állt rendelkezésre részletes instrukciókat tartalmazó leírás, oktatási programcsomag a hazai „innovátor” intézményvezetők számára. Ennek következtében, a KIP helyi innováció eredményeként sok tekintetben kiegészült az eredeti, stanfordi módszerhez képest, ami jó példája annak, hogy megfelelő irányítással, kutatásokkal, mérésekkel alátámasztva hogyan változtat meg egy pedagógusközösség egy adott módszert, a helyi körülményekhez igazodva, és feltöltődve a vezető és a pedagógusok 
kreatív alkotásainak eredményeivel. A KIP tehát több mint adaptáció, nem csak egy, az iskolának a saját tevékenységébe beillesztett olyan gyakorlat, amelyet más intézmények (például a Stanfordi Egyetem gyakorlóiskolái) már sikeresen alkalmaznak. Nem is csak egy eljárás vagy technika adaptálása. A KIP fejlesztési célokkal párosuló intézményi innováció, amely a következő lépésekben zajlott:

- A fennálló körülmények hatására a szükséglet megfogalmazása az innovációval szemben.

- Egy már működő modell tanulmányozása, adaptálása.

- A megismert modell folyamatos fejlesztése, formálása, innoválása új elemek megjelenésével.

- A modell disszeminációja.

A KIP tehát egy alulról jövő kezdeményezés, innováció, a pedagógusok módszertani kultúráját dúsító metódus. Kifejlesztése és bevezetése mellett az szólt, hogy az iskolában egyre több volt az alulmotivált, viselkedési problémával küzdő tanuló, amely probléma kezelésére a tantestület a pedagógiai megújulásban látta a megoldást. Az innovatív gondolkodásra nyitott tantestületben tehát létrejött a felismerés, hogy a problémák mérséklésére vagy megoldására való törekvés nem feltétlenül az intézmény falain kívül, hanem azon belül is elindítható és kivitelezhető folyamat. Az iskolavezető úgy látta, hogy mivel az igény, a reformmal ellentétben, a tantestületen belül fogalmazódott meg, nagyobb esély van arra, hogy a pedagógusok által létrehozott változás tartós lesz. A vezető által több hazai és külföldi program megismerése, megismertetése és elemzése után a figyelem a Stanford Egyetemen kidolgozott (Cohen, Lotan \& Leechor, 1989) Complex Instruction felé fordult, amelynek adaptációja 2000-ben kezdődött meg, majd 2003-ra új innovációt létrehozva, Komplex Instrukciós Program néven jelent meg a szakmai közönség előtt. Mint az a fentebb leírtakból érzékelhető, a KIP bevezetésével komoly szemlélet és módszerbeli változás, váltás mellett döntött egy tantestület, amelynek az eredménye egy sikeres hazai innováció lett.

\section{A Komplex Instrukciós Program rövid bemutatása}

A Komplex Instrukciós Program önerős fejlesztés eredményeként létrejött, pedagógiai módszerbeli váltást, változást igénylő, speciális csoportmunka-szervezésen alapuló módszer (Cohen \& Lotan, 2014). A program olyan, az egyes tantárgyak tekintetében értelmezendő, szocializáltságban és tudásban heterogén tanulói összetételt feltételező oktatási eljárás, amely eredményesen alkalmazható a tanulók 
tantárgyi, osztálytermi, illetve iskolai sikerességének megalapozásához. A módszer célja, hogy minden gyermek tudásszintje emelkedjen, és sikerélményben legyen része az osztálymunka során. A KIP tehát a tanórákon alkalmazható, az esélyegyenlőség megteremtésének feladatát vállaló, a kooperatív tanulási módszert előtérbe állító, komplex, alapelvekből és a tanórákon alkalmazott szabályokból felépülő rendszer. A technikai lényeget tekintve a KIP a pedagógusok rendelkezésére álló módszer-együttes, a tanórákon a pedagógus és a tanulók által végzendő tevékenységek egy adott ütembe illesztett rendszere (K. Nagy 2007, 2012, 2015), ${ }^{1}$ amelynek pedagógiai szempontból fókuszai a tanulói státuszkezelés, az esélyegyenlőtlenség csökkentése, az együttműködés a csoport- és egyéni munka során. A „KIP órák” (minden tantárgyból a tanórák körülbelül 10-20\%-a) úgy szerveződnek, hogy azokon a csoportmunka és a differenciált egyéni munka, a személyre szabott fejlesztés, azonos hangsúllyal szerepel. A kognitív képességek fejlesztése mellett a felelősség a tanulók saját munkája iránt, a kölcsönös bizalom, a pozitív hozzáállás és a segítőkészség a jó csoportmunka velejárói. A gyerekek a közös munka során empátiát, toleranciát, kooperációt, konfliktuskezelést, kommunikációt, kompromisszumkészséget tanulnak, miközben vitakultúrájuk, szervezőkészségük csiszolódik. A hejőkeresztúri iskola 70\%-os hátrányos helyzetű tanulói összetétele ellenére minden gyerek továbbtanul, 65-70\%-uk érettségit adó intézményben, amely mutató a program bevezetésekor $25 \%$ körül mozgott. ${ }^{2}$

\section{A program sikerességének feltételei és a disszemináció}

A fejlesztési célú beavatkozások sikeressége több tényezőtől függ, azonban az egyik legfontosabb alapelv, hogy a programot átvevők részéről a kitűzött célok iránti elköteleződés magas legyen, és lokális szinten is támogassák az adott programot az azt alkalmazók (Halász \& Szöllősi, 2012). Ezen gondolat értelmében a KIP sikerességéhez szükség van a bevezetés megfelelő fenntartói, vezetői és a pedagógusközösség tekintetében deklarált támogatására, de a fenntarthatóság biztosítására és a motiváció magas szinten tartására is.

Ezen a ponton eljutottunk a duplahurkos kör koncepciójához. A „virtuous circle" koncepciója alapján a KIP sikerét, kívánt szinten történő alkalmazását két egymást erősítő folyamat táplálja. Az egyik a programot adaptáló tantestület pedagógiai kultúrája formálására való hajlandóságának megléte - a programnak a tantes-

\footnotetext{
${ }^{1}$ Nahalka István (2011). Hejőkertesztúri IV. Béla Körzeti Általános Iskola és Napközi Otthonos Óvoda Esettanulmány

${ }^{2}$ A hasonló tanulói összetételű iskolákban ez az arány $40 \%$.
} 
tület minden tagja által történő elfogadása - a program megfeleló hatékonysága KIP elfogadása hurok, míg a másik hurok folyamatai az egyéni attitűdből fakadnak: a program megfeleló gyakorisággal történő alkalmazása - eredmények jelentkezése - KIP elfogadása (K. Nagy, 2015) (1. ábra).

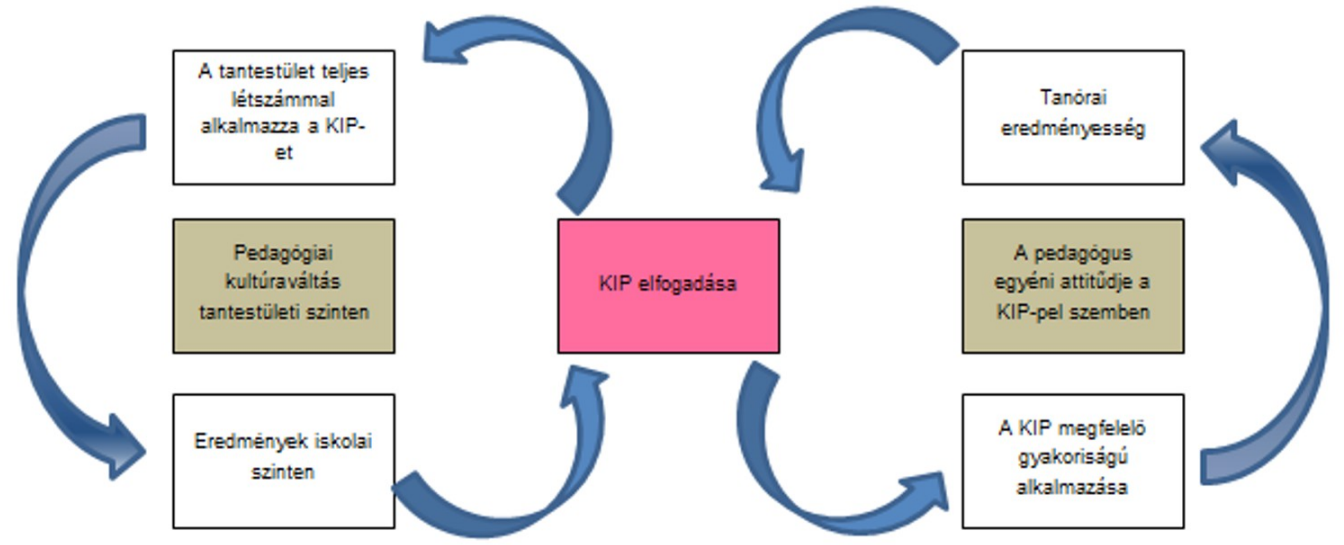

1. ábra: A duplahurkos kör koncepciója a KIP elfogadásáról

A program tapasztalatait megosztottuk az érdeklődőkkel, és igény szerint segítettük annak helyi adaptációját. Mára már közel 200 iskola több mint 20000 tanulója és közel 2000 pedagógusa döntött úgy, hogy eleget tesz a KIP alkalmazása ezen kívánalmainak. A programot alkalmazó iskolák összetételükben igen különbözőek. Van olyan iskola, ahol a tanulók közel 100\%-a hátrányos helyzetủ, de van olyan iskola is, amelyikben elhanyagolható, mindössze pár százalék a hátrányos helyzetű tanulók aránya. Figyelemreméltó az egyházi és a középiskolák bekapcsolódása is a programba.

\section{Összegzés}

A Komplex Instrukciós Program olyan tanítási-tanulási stratégia, amelynek eredményeképpen a hagyományostól eltérő módszerrel érhető el siker a tudásban és a szocializáltságban heterogén tanulói csoport nevelésében, oktatásában. Alkalmazása a pedagógus számára újdonságot, szakmai kihívást jelent egy új tanulás-tanítási módszer elsajátítása tekintetében, amely folyamatos felkészülésre, innovatív alkotómunkára készteti őket. Ugyanakkor a KIP innovációjának sikeréhez nem elég az egyén szintjén zajló változás, szükség van a szervezeti kultúra változására is, és az is nyilvánvaló, hogy nem elég a viselkedés megváltozása, hanem a moti- 
vációs rendszerek és kollektív kognitív sémák komplex változására is szükség van.

\section{Irodalomjegyzék}

Cohen, E. G. \& Lotan, R. A. (2014). Designing groupwork: Strategies for heterogeneous classrooms. Teacher College, Columbia University.

Cohen, E. G., Lotan, R. A. \& Leechor, C. (1989). Can classroom learn? Sociology of Education, 62, 75-94.

Halász, G. (2007). Tanulószervezet - eredményes oktatás. Új Pedagógiai Szemle, 2007(3-4), 37-45.

Halász, G., Fazekas, Á. \& Lukács, T. (Eds.) (2020). Az innovációs folyamatok dinamikája az oktatási ágazatban. Akadémiai Kiadó.

Halász, G. \& Szőllősi, T. (2012). A fejlesztő beavatkozások hatásmechanizmusainak kérdései a nemzetközi fejlesztőszervezetek tevékenységében. ELTE PPK Felsőoktatás-menedzsment Intézeti Központ. Kézirat (http://www.fmik.elte.hu/aszervezeti-egyseg-bemutatasa/a-kozoktatas-fejlesztesibeavatkozasokhatasmechanizmusai/produktumok/)

K. Nagy, E. (2007). Integrációs modell. A hejőkeresztúri IV. Béla Körzeti Általános Iskola tevékenysége. Fókusz, 9(1), 36-56.

K. Nagy, E. (2012). Több mint csoportmunka. Nemzeti Tankönyvkiadó.

K. Nagy, E. (2015). KIP könyv I-II. Miskolci Egyetem.

Nahalka, I. (2011). Hejőkertesztúri IV. Béla Körzeti Általános Iskola és Napközi Otthonos Óvoda - Esettanulmány.

Oslo Manual 2015.

https:/ec.europa.eu/eurostat/documents/3 859598/5 889 925/OSLO-EN.PDF/ 60a5a2f5-577a-4091-9e09-9fa9e741dcf1 (2020. 04. 10) 


\section{The success of school innovations: the Complex Instruction Program in focus}

The aim of the paper is to explore why and how the Hungarian Komplex Instrukciós Program, that is suitable for the successful treatment of academically heterogeneous groups, has become a known and accepted method. We are looking for an answer why it has been introduced by nearly a hundred schools, regardless of whether they are disadvantaged or have an elite student community.

In this article, we focus on comparing the concepts of reform and innovation, as we believe that choosing between the two is the primary determinant of school success. In this context, we point out how the efficiency of schools is affected by a top-down initiative, i.e. reform, and a bottom-up decision, i.e. innovation.

Keywords: innovation, complex, instruction, program, CIP 